\title{
Cortesía, falsa cortesía y descortesía en los entremeses de Miguel de Cervantes*
}

\author{
CARMela PÉReZ-SalazaR**
}

\begin{abstract}
Resumen
En este trabajo se presenta un análisis del comportamiento verbal cortés y descortés en el Siglo de Oro a través de una fuente excepcional: los ocho entremeses de Miguel de Cervantes. La amplitud de la representación social y la variedad de los personajes que intervienen en estas piezas, $y$, especialmente, la singularidad de las situaciones que se producen en escena, a menudo generadoras de conflictos, favorecen la aparición de recursos verbales indicadores de deferencia, y, con más frecuencia, de formas que desprecian o atacan la imagen de los interlocutores. A ello se suma la finalidad esencialmente lúdica de los entremeses, que propicia la originalidad del autor, canalizada en la creación y la multiplicación de formas descorteses.
\end{abstract}

Palabras clave: Cervantes; entremeses; (des)cortesía; burla.

Title: Politeness, Feigned Politeness and Impoliteness in Miguel de Cervantes' Entremeses or Short Farces

\begin{abstract}
This paper analyzes the (im)polite verbal behavior in the Spanish Golden Age through an exceptional source: the eight entremeses (short farces or theater interludes) by Miguel de Cervantes. The wide social representation and the variety of characters intervening in these pieces and, especially, the singularity of the staged situations -with a predilection for conflicts-, contribute to the use of deferential verbal forms and -more often- forms that ignore or attack the interlocutors' face. To this we may add the main ludic purpose of the
\end{abstract}

* Este trabajo se enmarca en el proyecto FI2017-82532-P MINECO/AEI/FEDER, UE, «Identidades y alteridades. La burla como diversión y arma social en la literatura y cultura del Siglo de Oro», Ministerio de Economía, Industria y Competitividad-Agencia Estatal de Investigación del Gobierno de España.

** Universidad de Navarra. GRISO.cpsalazar@unav.es / ORCID iD: https://orcid.org/0000$0003-2139-8153$ 
entremeses that boosts the author's creativity, manifested in the creation and multiplication of impolite forms.

Keywords: Cervantes; entremeses (Short Farces); (Im)politeness; Derision.

\section{Cómo citar este artículo / Citation}

Pérez-Salazar, Carmela. 2021. «Cortesía, falsa cortesía y descortesía en los entremeses de Miguel de Cervantes».Anales Cervantinos 53:263-291.https://doi.org/10.3989/anacervantinos.2021.011

\section{INTRODUCCIÓN}

En todas las sociedades existen pautas de comportamiento destinadas a facilitar los intercambios personales. El conjunto de convenciones o normas que regulan la armonía en la interacción humana -lo que denominamos cortesía- se manifiesta, sin embargo, particularmente, de acuerdo con factores cronológicos, socioculturales o idiosincrásicos (Kerbrat-Orecchioni 2004, 39-41).

El análisis de la cortesía verbal, desarrollado por la pragmalingüística ${ }^{1}$, se ha fundamentado originalmente en el concepto de imagen social (Brown y Levinson 1987, 61-74) ${ }^{2}$ : todo individuo quiere ser aceptado y reforzado (imagen positiva), y desea, además, que sus actos no se vean impedidos (imagen negativa). Cuando se produce una interacción verbal $-\mathrm{y}$, por tanto, puede ponerse en riesgo la imagen de los interlocutores- es posible que se activen estrategias que refuercen la imagen positiva o la imagen negativa de estos conforme a los usos del contexto cultural: se dice de las culturas anglosajonas que elaboran especialmente estrategias de cortesía negativa, esto es, que expresan respeto a la voluntad del receptor, y de las mediterráneas en general, que tienden a manifestar estrategias de cortesía positiva, es decir, enfatizan la solidaridad entre los interlocutores, evitan presentar la propia opinión y minimizan el disentimiento ${ }^{3}$.

1. Véase Brenes (cap. 1) para una reflexión acerca de los métodos en los que se ha basado el análisis de la cortesía (pragmalingüístico y sociopragmático), que conviven y ofrecen visiones complementarias de una misma realidad. Brenes Peña, María Ester. 2009. La agresividad verbal y sus mecanismos de expresión en el español actual. Tesis doctoral. Accesible en: <https://idus.us.es/xmlui/ handle/11441/15333>.

2. Una revisión de las reacciones que suscitó la teoría de Brown y Levinson en cuanto a su universalidad en Bravo y Briz (2004) y Kerbrat-Orecchioni (2004), que propone una concepción más positiva de la cortesía.

3. Haverkate (1994, 12-13) diferencia culturas de acercamiento y culturas de distanciamiento. Kaul de Marlangeon $(2017,6)$ describe la cultura hispanohablante como de acercamiento, frente a culturas de distanciamiento, como la anglosajona o la escandinava. Kerbrat-Orecchioni (2004, 48-50) ofrece testimonios de variación cultural en cuanto a los comportamientos de cortesía, en sus aspectos cuantitativo y cualitativo. 
Otros factores determinan también el uso y la regulación de estrategias. La finalidad del intercambio permite distinguir actos verbales corteses en sí mismos (los actos expresivos -saludos, halagos-), que suelen activar procedimientos socializadores; actos no corteses (los asertivos o exhortativos), que pueden neutralizarse con estrategias mitigadoras (Haverkate 1994, caps. 7 y 8$)^{4}$; y actos descorteses, orientados a dañar la imagen del otro ${ }^{5}$. Si no es cortés evitar el uso de procedimientos mitigadores allá donde se esperan, otros comportamientos -que suelen surgir en situaciones generadoras de conflicto- son explícitamente descorteses: la selección de un tratamiento que menoscabe la categoría social del interlocutor ${ }^{6}, o$, más aún, los insultos, maldiciones, burlas y amenazas (por citar las agresiones verbales que se encuentran en los entremeses cervantinos) son comportamientos que dañan la imagen social ${ }^{7}$.

La simetría o asimetría de la relación verbal según la edad, el sexo o el grupo social al que pertenecen los participantes conforme a las expectativas de comportamiento que imponen las coordenadas espaciotemporales, condicionan asimismo la selección de recursos. Es conocida, al respecto, la rigidez de la división social en la España medieval y del Siglo de Oro -rigidez en crisis a comienzos del siglo $\mathrm{XVII}^{8}$ - que se refleja, por ejemplo, en la distribución de las formas y fórmulas de tratamiento. Tratadistas y gramáticos muestran, a los ojos del investigador de hoy, el reparto de pronombres, personas verbales y títulos de honor, vinculados al grupo social de los interlocutores (Lapesa 2000, 319) -las «calidades de las personas», en palabras de Correas $(1635,213)-$, y a las circunstancias de poder o solidaridad en que

4. La distinción de Haverkate se basa en la tipología de los actos de habla establecida por Searle $(1976,10-16)$.

5. Es habitual la consideración de la cortesía y la descortesía como dos polos de un continuo en el que se pueden establecer grados según la intención del hablante y la lesión que inflige en el destinatario; así en Culpeper (1996) y Kaul de Marlangeon (2008).

6. Lo inadecuado de este comportamiento se constata con frecuencia en el Siglo de Oro español: «Quien llamase de vos a otro, no siendo muy más calificado, le menosprecia y haze ultrage en nombralle, pues se sabe que con semejantes palabras llaman a los peones y travajadores», escribe Gracián Dantisco a fines del siglo XVI (Gracián Dantisco 1593, 132). Enguita $(1986,297)$ recupera, a propósito de la inquietud social hacia las fórmulas de tratamiento, el testimonio que recoge en una carta Diego Hurtado de Mendoza: «El secretario Antonio de Eraso llamó de vos a Gutierre López, estando en el Concejo, y por esto se acuchillaron». Frago $(2005,296)$ recuerda que el deseo de denigrar al interlocutor podía manifestarse en un cambio en el tratamiento, como se observa, por ejemplo, en varios testimonios del Buscón.

7. Kaul de Marlangeon (2017, cap. 2.1.) describe la descortesía como una conducta vinculada a las emociones; insultos, críticas, agravios, reproches, sarcasmos y burlas manifiestan emociones negativas, tanto en quien produce el acto descortés como en quien lo recibe.

8. La organización social que hereda la España del Siglo de Oro ofrece síntomas de cambio: el sistema estamental comienza a perder rigidez por razones económicas; algunos miembros de las clases bajas se acercan, por su poder adquisitivo, a estamentos superiores; al contrario, la pobreza de hidalgos y otros representantes de la nobleza más baja los coloca en una posición más cercana a los desfavorecidos. Fernández Álvarez (1984, 153-234) describe la sociedad española del siglo XVI y ofrece un panorama de algunos conflictos del siglo XVII -política y religión; mundo rural y urbano; promoción social; sentimientos antifeudales- a través de las obras teatrales de las grandes figuras. 
sucede el intercambio (cfr. infra, cap. 3.1.) $)^{9}$. A pesar de la regulación oficial de los tratamientos y otras formas indicadoras de cortesía ${ }^{10}$, no faltan testimonios de desórdenes y alteraciones (e incluso de parodias), que se producían en el uso de un sistema excesivo ${ }^{11}$ :

Y assí viendo esto la nobleza de cavalleros y gente calificada, se han aprovechado de subirse un grado o dos más arriba, para poderse diferenciar, especialmente en las cartas, de esta generación robadora de sus illustres títulos (Gracián Dantisco 1593, 134-135).

Dévese tamvien notar mucho la desorden i discordante concordia que á introduzido el uso, ora por modestia, ora por onrra, ó adulazion (Correas $1635,213)$.

Las dificultades de combinar todo este entramado de factores -en particular si el objeto de análisis se sitúa en algún momento del pasadono han impedido el interés creciente por las manifestaciones de la cortesía y la descortesía verbal ${ }^{12}$. En lo que respecta al estudio histórico del español, cabe recordar que los estudios que versan sobre las formas de tratamiento -en las que se codifica la deíxis social- recorren varias décadas $^{13}$; solo respecto de la fórmula vuestra merced, la descripción, a

9. Brown y Gilman (1960) proponen las dimensiones de poder y solidaridad para diferenciar los ejes vertical y horizontal, respectivamente, de las relaciones sociales, es decir, la asimetría y la simetría, de acuerdo con el lugar que ocupan los interlocutores en la escala social. Según indican Brown y Levinson $(1987,74-84)$ el grado de cortesía aumenta cuanto mayor es la distancia social entre hablante y oyente, cuanto mayor es el poder del oyente sobre el hablante y cuanto mayor es el grado de imposición del hablante hacia el oyente. Moreno Fernández (2015, 150-151) explica que, en las relaciones de poder, la falta de reciprocidad puede estar basada en muchas realidades: riqueza, edad, fuerza física, posición social, tipo de parentesco, pertenencia a instituciones, etc.

10. Felipe II firma, en 1586, la Pragmática en que se da la orden y forma que se ha de tener y guardar en los tratamientos y cortesías de palabra y por escripto (Lapesa 2000, 318-319). Véase Martínez Gavilán (1988) para una revisión de las formas de tratamiento en el siglo XVII según los datos que aportan los tratadistas.

11. Medina Morales (2004, 1330-1331) explica que las alteraciones en el complicado sistema de tratamientos se debieron a la actitud puntillosa de algunos sectores de la sociedad (clase media, baja nobleza, indianos enriquecidos...). Rodríguez Mansilla (2006, cap. 2) muestra la parodia del comportamiento cortés en algunas obras. El escudero del Lazarillo de Tormes y el capitán de Guzmán de Alfarache, señala, son "víctimas de una cortesía pervertida», y sus casos constituyen muestras de los cambios sociales que se estaban produciendo. Citaré los repertorios, tratados y gramáticas clásicos por la fecha original, que, en el apartado Bibliografía citada, aparece entre corchetes.

12. En concreto, la «laguna» de la que hablaba Haverkate al referirse a los estudios sobre cortesía en el ámbito hispánico (Haverkate 1994, 10) ha dado lugar a una situación que hoy se describe, por ejemplo, como un «campo en continua ebullición» (Albelda y Barros 2018, 6). El desarrollo que han experimentado los estudios sobre cortesía verbal en español-inaugurados por el propio Haverkate- sobrepasa cualquier expectativa. En cualquier caso, la perspectiva histórica aún se considera la menos atendida (Iglesias 2010, 370).

13. El relato de esa evolución se debe a filólogos imprescindibles, como recuerda Fernández Rodríguez (2003). La presencia de la perspectiva histórica en eventos científicos y publicaciones recientes se puede observar, por ejemplo, en Hummel, Kluge y Vázquez (2010), y en la relación bibliográfica que ofrecen, respecto de las formas de tratamiento, Fernández Rodríguez y Gerhalter (2016-2017). 
punto de cumplir un siglo, alcanza a explicar desde sus orígenes (Pla Cárceles 1923a y 1923b) hasta el anuncio de su desaparición, de la que se lamentaba Dámaso Alonso allá por 1947 (Alonso 1962) ${ }^{14}$. Generosa es, en concreto, la atención a la distribución de las formas y fórmulas de tratamiento en la literatura del Siglo de Oro $^{15}$, y lo mismo cabe decir de las manifestaciones de la descortesía, posiblemente porque a las noticias históricas sobre agresiones verbales y no verbales en este período, y a las pruebas documentales, se suma una producción literaria que deja constantes testimonios de realismo y creatividad canalizados en improperios, burlas y maldiciones ${ }^{16}$.

Con base en la corriente filológica tradicional, pero con el auxilio de la pragmalingüística ${ }^{17}$, en estas páginas me propongo revisar algunos comportamientos verbales relacionados con la (des)cortesía en una fuente excepcional, los ocho entremeses de Miguel de Cervantes ${ }^{18}$, que, por sus características -además del tiempo y lugar, las relativas al género: situaciones, interacciones, personajes, como expondré a continuación- invitan al análisis de esta cuestión. Me propongo mostrar que los comportamientos verbales corteses, falsamente corteses y descorteses sirven al autor para obtener distintos efectos, y que, al mismo tiempo, desprenden información sobre la lengua y la sociedad de su tiempo.

14. Véase Sáez Rivera (2006) para una revisión de las aportaciones que tratan la evolución vuestra merced $>$ usted, y para un análisis de esta evolución como un proceso de gramaticalización en el que, desde el punto de vista fonético, se produjo la estratificación en varias formas, de las que sobrevivió una, usted, por especialización o fijación. En el siglo XVIII, perviven vuste(d) y uste(d) en el habla y, en el uso escrito, vuestra merced y vuesa merced.

15. Sin pretender ser exhaustiva, los trabajos de Ly (1981), Enguita (1986), Del Barrio (1997), Haverkate (2001), Bañón Hernández (2001), García Gallarín (2002), Pérez-Salazar (2002; 2018), Medina Morales (2004, 2005), Frago (2005), Iglesias Recuero (2010), King (2010), fundamentados en fuentes literarias y no literarias, dan testimonio de un interés prolongado e ininterrumpido por los sistemas de tratamiento (y la cortesía) en el Siglo de Oro.

16. Véase el volumen editado por Pérez-Salazar et al. (2013), que reúne contribuciones históricas, lingüísticas y literarias sobre improperios y maldiciones en fuentes diversas del Siglo de Oro.

17. Perspectiva que, como recuerda Fuentes Rodríguez $(2000,53)$, incorpora el contexto sociocultural, imprescindible, por razones obvias, en trabajos sobre cortesía.

18. Sigo la edición de Alfredo Baras (2012) publicada por la Real Academia Española en 2012. En los testimonios me referiré a cada pieza del modo que sigue: Juez (El juez de los divorcios); Rufián (Entremés del rufián viudo llamado Trampagos); Alcaldes (Entremés de la elección de los alcaldes de Daganzo); Guarda (Entremés de la guarda cuidadosa); Vizcaíno (Entremés del vizcaíno fingido); Retablo (Entremés del retablo de las maravillas); Cueva (Entremés de la cueva de Salamanca); Viejo (Entremés del viejo celoso). Tras la mención de la pieza, indico la(s) página(s), y, en su caso, los versos. 


\section{LOS ENTREMESES DE CERVANTES, FUENTE EXCEPCIONAL PARA EL ESTUDIO DE LAS RELACIONES SOCIALES Y LA (DES)CORTESÍA VERBAL EN EL Siglo DE ORO}

La elección de los entremeses cervantinos para el análisis de la (des)cortesía no es fortuita. Expongo, a continuación, algunos rasgos que revelan la idoneidad del género y las singularidades del Cervantes entremesista.

Pese a tratarse de un género literario, el protagonismo de los entremeses reside en las situaciones y el lenguaje, más que en el propio texto (González Maestro 1998, 593; Zimic 1992, 24), y en su peculiar mezcla de realidad y ficción en asuntos, personajes y formas expresivas (Arellano 1995, 660-661).

Asensio $(1971,17)$, que recuerda la primera definición del entremés, la que ofrece el Diccionario de autoridades:

Representación breve, jocosa y burlesca, la cual se entremete de ordinario entre una jornada y otra de la comedia para mayor variedad o para divertir y alegrar al auditorio,

describe otras singularidades. Las isoglosas del entremés, explica, penetran en géneros vecinos, dramáticos y no dramáticos, de los que recibe alimento y renovación: las facecias le prestan anécdotas y episodios; la Celestina y la narrativa picaresca, el diálogo cómico y la cantera de tipos y situaciones procedentes de las capas inferiores de la sociedad; de la comedia, de la que nace y se desgaja como pieza independiente, adopta, además del carácter teatral, la comicidad y la figura del bobo, aunque esta sea mucho menos compleja que la del gracioso. De esta forma, concluye, «el entremés es un género inestable, perpetuamente buscando su forma, zigzagueante entre la historieta y la revista, la fantasía y el cuadro de costumbres») (Asensio 1971, $25-40)^{19}$.

Si a Lope de Rueda se le reconoce como creador del entremés, a Quevedo como prodigio en la inventiva verbal (Arellano 1995, 665) y a Quiñones de Benavente como especialista por antonomasia, a Cervantes se le atribuye la incorporación de técnicas de la novela, tales como la continuidad de la narración o la construcción de personajes de cierta complejidad (Asensio 1971, 99-110). Aunque Cervantes mostró, según se dice, poca originalidad al tomar sus personajes de la tradición, tuvo la habilidad de convertir los arquetipos en menos convencionales; los personajes cervantinos son «seres de carne y hueso que hablan una lengua de múltiples registros, oída en la calle pero sometida a un proceso renovador» (Baras 2012, IX). Abundan, de hecho, las consideraciones que destacan la pericia de Cervantes en la construcción del

19. Asensio señala también las diferencias de la comedia y el entremés: además de la extensión, las que distinguen el gracioso de la comedia del bobo del entremés, o la finalidad del carácter jocoso, que en los entremeses solo busca sorprender. 
diálogo 20 : «Los diálogos cervantinos no son los de la lengua hablada, pero sí están construidos en la lengua de la oralidad literaria, configurada con elementos de la lengua viva, pero construida al servicio de una situación escénica» (Bustos Tovar 1996, 287).

Conviene, en este punto, recordar la reflexión que ha merecido, para el conocimiento de la oralidad, la legitimidad de ciertos textos ${ }^{21}$, fuentes ineludibles, por razones obvias, en el estudio histórico de la lengua. Si, en lo que respecta a la creación literaria, la actitud más prudente advierte de la voluntad estética y la ficción como rasgos que la diferencian de la oralidad real ${ }^{22}$, no faltan quienes argumentan que los escritores han de ser, además de creadores, observadores de los usos lingüísticos y de su correlación con determinados factores sociales (Bañón Hernández 2001, cap. 1) 23. La idoneidad, en concreto, de las piezas dramáticas para el estudio sociolingüístico se fundamenta en la verosimilitud del lenguaje, pero también en el conocimiento del sistema de valores de una época que el género impone al autor (Gancedo 2016, 164-167), en su naturaleza discursiva y en la variedad de situaciones que ofrecen (Iglesias 2010, cap. 1.2.1.) $)^{24}$.

La sencillez del entremés desde el punto de vista dramático es compatible con una representación social generosa. En concreto, en los entremeses de Cervantes aparecen ochenta y siete personajes: sesenta y seis hombres y veintiuna mujeres, diversos en edad, grupo y dedicación (Baras 2012, 184) ${ }^{25}$. Intervienen en estas ocho piezas jóvenes y viejos, acomodados y, preferentemente, gentes del pueblo, incluidas las capas más bajas de la sociedad.

20. Con frecuencia se subraya la capacidad de Cervantes para crear diálogos (véase Bustos Tovar 1996, 277-283, que destaca los hallazgos expresivos de este autor; y Frago 2005, cap. 5); Baras (2012, 186-191) menciona, además, la laguna que existe al no disponer de monografías sobre el diálogo, y se lamenta de no poder fijar la relación entre los diálogos cervantinos y el habla de la calle y del campo.

21. Oesterreicher (1996) tipifica las fuentes escritas que permiten observar rasgos de la denominada inmediatez comunicativa. Bustos Tovar (1998) analiza el diálogo teatral y su trayectoria desde Rueda.

22. Bustos Tovar (1996, 282-287; 1998, 423-425) compara el diálogo teatral (construido literariamente) y la conversación coloquial. González Maestro (1998) explica la importancia del diálogo dramático y tipifica las formas de expresión dialógica en los entremeses.

23. El volumen editado por Baranda y Vian (2006) reúne trabajos que reflexionan sobre la codificación escrita de la oralidad en los personajes literarios del siglo XVI. En el capítulo introductorio (7-11), las editoras se refieren al «pacto ficticio» que existe entre autor y lector en la obra literaria, y a la diversidad de pactos ficticios según las obras, los géneros y los personajes.

24. Bustos Tovar $(2006,34-39)$ considera que la plena incorporación de la oralidad a lo escrito sucede, en el Siglo de Oro, en textos como La lozana andaluza, en los que la mímesis deja paso a la textualización del diálogo conversacional y los personajes ya no solo hablan, sino que también actúan, y, por tanto, decir y hacer pasan a constituir un todo. Textualizar la oralidad no consiste en escribir como se habla, afirma, sino en crear un discurso en el que se transmite el comportamiento de los personajes. Para Frago $(2005,301)$ «los textos literarios suelen reflejar mejor que los eruditos el complejo entramado de las relaciones sociales y el funcionamiento de las fórmulas de tratamiento personal».

25. El editor recoge los contabilizados por Agostini (1964), que muestra también la proporción de hombres y mujeres en cada una de las piezas, y los clasifica según su clase, dedicación e incluso carácter. 
Junto a algunos representantes de la autoridad (juez, gobernador, regidores) y miembros del clero (sacristanes) y del ejército (siempre en el grado más bajo), desfila por las tablas un amplio elenco de oficios: escribanos, cirujanos, estudiantes, barberos, criados, campesinos, titiriteros, alcahuetas, prostitutas...

A la pluralidad y diversidad social, que hace posibles los encuentros e intercambios entre iguales y desiguales $\mathrm{y}$, por tanto, propicia las relaciones de solidaridad y de poder, cabe añadir la disparidad de sucesos en los que se sustenta cada uno de los ocho entremeses. Así resume el editor (Baras 2012, IX) lo que ocurre en estas ocho piezas:

Un juez deja en suspenso la sentencia de divorcio de cuatro matrimonios mal avenidos que le refieren sus desventuras. Fallecida una prostituta, su rufián lamenta la irreparable pérdida tan solo hasta el momento de hallar nueva pareja. Cuatro candidatos a alcaldes exponen sus discutibles habilidades ante los regidores del pueblo. Un soldado y un sacristán, enamorados de una fregona, ponen fin a sus disputas sometiéndose a la elección de su amada. Dos cortesanos engañan a una prostituta con dos cadenas de oro, verdadera y falsa, haciéndose pasar uno de ellos por vizcaíno. Tres burladores muestran a unos aldeanos su maravilloso retablo visible solo para quienes sean hijos legítimos y no desciendan de conversos. Leonarda y su criada cenarán en casa con el sacristán y el barbero; vuelto el marido, un estudiante deberá hacer uso de su ingenio para convertir a los dos amantes en diablos. Con ayuda de una vecina, Lorenza hace entrar y salir a un galán en presencia de su esposo y le describe su encuentro sin que nada sospeche.

A partir de estas situaciones y acontecimientos, pintorescos, pero verosímiles, no puede extrañar que surjan intercambios verbales potencial o manifiestamente conflictivos: disputas conyugales y de galanes, concursos de aldeanos y de prostitutas, escenas de celos, preparativos de burlas, encuentros amorosos ocultos... Además, teniendo en cuenta que los entremeses son piezas jocosas y burlescas, cabe esperar una mayor presencia de la descortesía y de la falsa cortesía que de la cortesía: primero, porque la burla es esencialmente descortés, $\mathrm{y}$, además, porque los comportamientos descorteses favorecen -antes y ahora- mucho más el entretenimiento del público ${ }^{26}$ que la deferencia y la armonía (bastaría recordar, para justificar esta afirmación, la audiencia que cautivan en la actualidad programas de televisión por los que desfilan todas las posibles manifestaciones de la descortesía).

26. Como explica Lobato $(2005,284)$ respecto de los entremeses de burlas de Cervantes, «si la burla no redunda en el mal del burlado, podemos pensar con Cervantes que su fin es más ligero y está más próximo a la diversión que a la ofensa de quien la recibe». 


\title{
3. CORTESÍA, BURLAS Y OTRAS FORMAS DE DESCORTESÍA EN LOS ENTREMESES DE CERVANTES
}

\subsection{Vuesa merced, vuesas mercedes. El tratamiento codificado y otras expresiones corteses}

Indicaba arriba que la sociedad española del Siglo de Oro impone pautas de comportamiento verbal rigurosas. Baste recordar el sistema de tratamientos vigente a comienzos del siglo XVII (época de redacción de los entremeses), que se organiza en cuatro formas fundamentales y varios títulos de honor, y cuyo empleo se basa en el rango social y en la edad de los interlocutores, además de la intención (dar honra, gravedad, cumplimiento, respeto; reñir, mostrar enojo; adular, encarecer...), tal como explica, bien entrada la centuria, Gonzalo Correas $(1635,363)$ :

\begin{abstract}
Es menester primero advertir que se usan quatro diferenzias de hablar para quatro calidades de personas, que son: vuestra merzed, él, vos, tu [...] De merzed usamos llamar à las personas à quien rrespetamos, i debemos ò queremos dar onrra, como son xuezes, cavalleros, eclesiasticos, damas, i xente de capa negra, i es lo mas despues de señoria.

Él usan los maiores con el que no quieren darle merzed, ni tratarle de vos, que es mas baxo, i propio de amos á criados, i la xente vulgar i de aldea, que no tiene uso de hablar con merzed, llama de él al que quiere onrrar de los de su xaez. De vos tratamos à los criados i mozos grandes, i à los labradores, i à personas semexantes; i entre amigos adonde no ai gravedad, ni cunplimiento se tratan de vos, $i$ ansi en rrazonamientos delante de rreies i dirixidos á ellos se habla de vos con devido rrespeto i uso antiguo.

De tu se trata á los muchachos i menores de la familia, i á los que se quisieren bien: i quando nos enoxamos i rreñimos con alguno le tratamos de él, i de vos por desden.

Tanbien ai otros titulos i nonbres de onor con que hablamos à las personas i las hablamos sin el nonbre propio: à los Rreies dezimos Magestad; à los prinçipes Alteza; à los grandes Eszelencia; à otros titulados i obispos Señoria; à todos los otros Merzed [...] A los rreligiosos provinziales llaman Paternidad Rreverendísima; à los perlados, Paternidad; a los demás, Reverenzia, como digo. Solíase usar sin orden de otras adulaziones i encarezimientos: Magnífico, Illustre, Ilustrísimo; ia se quitó tal abuso por prematica rreal, i se rreservó para los señores i prelados.
\end{abstract}

Las manifestaciones de la cortesía verbal en los entremeses incluyen, como cabe esperar, recursos codificados en este sistema. Excluidos los «títulos y nombres de onor» de los que habla el gramático, que no aparecen en estas obras, me referiré al uso de vuestra merced -tratamiento respetuoso habitual ya en el siglo XVI, como explica Lapesa $(2000,319)^{27}$ :

27. Remito a Bañón Hernández (2001, cap. 2.1.) para un análisis del empleo de señor y don (además de so, sor, sora) en piezas literarias del Siglo de Oro; y a Frago (2005) para las formas 
De todas estas fórmulas, la más usada fue vuestra merced, que se extendió al tratamiento respetuoso general; rehusarla entre iguales era injurioso cuando no había mucha confianza, y era vejatorio regatearla a inferiores distinguidos. Así ocurría ya hacia 1530, y los testimonios literarios posteriores son muy abundantes,

y a su concurrencia contextual con otros recursos indicadores de cortesía-, y de vos, compatible con el respeto, como se verá, en los intercambios de superior a inferior.

Hay, en los entremeses, testimonios abundantes del uso del sintagma vuesa merced en singular y en plural (siempre en esa variante, que, conforme a las indicaciones de Valdés, era la más habitual; o, según explica Juan de Luna, era la que utilizaban los hablantes «comunes» ${ }^{28}$ ). Su presencia en los diálogos, recíproca o no, se rige por varias circunstancias que a menudo concurren: la condición social de los interlocutores, la simetría o la asimetría del intercambio y el tipo de acto de habla.

De acuerdo con el valor que le otorga Correas $(1635,363)$-de merced usamos llamar a las personas a quienes respetamos y debemos o queremos dar honra, como son jueces, caballeros, eclesiásticos, damas y gente de capa negra- y con la descripción que ofrece Covarrubias $(1611, s . v$. $)$-«Merced es una cortesía usada particularmente en España»-, la fórmula vuesa merced es la que corresponde al juez de los divorcios.

Valga destacar que las circunstancias de la comunicación favorecen en esta pieza la acumulación de estrategias indicadoras de respeto: el diálogo sucede en un contexto formal y en relación de desigualdad (parejas vs. juez, a cuyo juicio se someten); además, todas las intervenciones de los asistentes incluyen peticiones, y, por tanto, apelan a la voluntad del interlocutor, el juez. Así, junto al tratamiento, se acumulan recursos léxicos y gramaticales indicadores de cortesía, positiva (el vocativo señor juez) y negativa (los atenuadores de la petición: el verbo suplicar, el adverbio encarecidamente, la locución ser servido, el verbo en condicional querría, la fórmula condicional si fuese servido...):

MARIANA. Vuesa merced, señor juez, me descase, si no quiere que me ahorque (Juez, 4).

D. ${ }^{a}$ Guiomar. ¡Bendito sea Dios!, que se me ha cumplido el deseo que tenía de verme ante la presencia de vuesa merced, a quien suplico, cuan encarecidamente puedo, sea servido de descasarme deste (Juez, 7).

indicadoras de respeto en el Quijote, que combinan, indica el autor, la realidad sociolingüística de su tiempo con la impostación y el remedo de la lengua antigua que caracterizan al protagonista.

28. «Es bien verdad que la pronunciación más ordinaria es $\sin r$, como vos avéis muy bien notado» (Valdés 1535-1536, 184). Casi un siglo después, las explicaciones de Juan de Luna se refieren a las características del hablante: «Vuesaste, vuesa merced, vuestra merced, que significan vna mesma cosa, y no se muda segun la calidad de las personas (segun algunos piensan), pero esta mudança viene de parte del que habla, que si es de los mas ladinos dize vuesaste, el comun vuesa merced, y los mas rusticos vuestra merced» (Luna 1619, 165). 
CiRujano. Vengo a pedir a vuesa merced, señor juez, haga divorcio entre mí y la señora doña Aldonza de Minjaca (Juez, 11).

GANAPÁN. Querría, si vuesa merced fuese servido, o que me apartase della o por lo menos le mudase la condición acelerada que tiene (Juez, 13).

Puesto que la relación verbal es asimétrica (social y contextualmente), el tratamiento no puede ser recíproco -el juez se sirve siempre de la segunda persona de plural que corresponde a vos (Del Barrio 1997, 356) y a vosotros-, pero sí lo es el empleo de recursos indicadores de cortesía (los vocativos señora, señores, las formas que atenúan su respuesta negativa), e incluso de solidaridad; como se observa en los testimonios que siguen, las expresiones de consuelo y la asunción del compromiso son adhesiones a la causa de los interlocutores:

JuEz. No lloréis, señora; bajad la voz y enjugad las lágrimas (Juez, 4).

JuEZ. Mirad, señores, aunque algunos de los que aquí estáis habéis dado algunas causas que traen aparejada sentencia de divorcio, con todo eso, es menester que conste por escrito y que lo digan testigos; y así, a todos os recibo a prueba (Juez, 13).

La reciprocidad del tratamiento de vuesa merced se debe a circunstancias sociales - permanentes- o vinculadas al intercambio verbal. Se encuentra, por ejemplo, entre iguales de clase acomodada ${ }^{29}$, como doña Lorenza y Hortigosa, protagonistas de El viejo celoso. Obsérvese, en cualquier caso, que, si bien las dos se llaman señora, a esta última - ¿tal vez por ser vecina y «hortigosa», como explica el propio protagonista Cañizares? ${ }^{30}$ - no le corresponde un doña:

D. ${ }^{a}$ LORENZA. Milagro ha sido este, señora Hortigosa, el no haber dado la vuelta a la llave mi duelo, mi yugo y mi desesperación [...]

HoRTIGOSA. Ande, mi señora doña Lorenza, no se queje tanto, que con una caldera vieja se compra otra nueva [...]

Hortigosa. Ahora bien, señora doña Lorenza, vuesa merced haga lo que le tengo aconsejado [...]

D. ${ }^{a}$ LORENZA. Señora Hortigosa, váyase, no venga el gruñidor y la halle conmigo, que sería echarlo a perder todo, y lo que ha de hacer, hágalo luego (Viejo, 119-122).

29. King $(2010,541)$ explica que el uso recíproco de vuestra merced se limita, en las obras literarias que analiza, a los diálogos entre desconocidos, y el no recíproco se emplea en las relaciones con el poder. La misma fórmula se emplea entre iguales de clase acomodada en el Quijote (Del Barrio 1997, 355 y 359-360). Fontanella $(1999,1411)$ observa, en un grupo de cartas escritas por emigrantes en el Siglo de Oro, que la fórmula $V . M$. era exclusiva en las relaciones asimétricas de menor a mayor.

30. «¿Hortigosa y vecina? Dios sea conmigo», dice Cañizares (Viejo, 127). Anota el editor que Hortigosa está formado a partir de hortiga, planta que pincha y que, además, empleaban las alcahuetas. A ello se añade su condición de vecina, como explica el protagonista de la pieza, Cañizares: «Nombre fatal para mí es el de vecina» (Viejo, 119, nota 1). 
Si el trato deferente mutuo está determinado por las circunstancias del intercambio, puede ocurrir que se modifique, porque cambian las circunstancias, en el transcurso de la comunicación. A los cuatro candidatos a alcalde de Daganzo, labradores, pero «hombres de chapa y caletre» (Alcaldes, 35), los reciben los componentes del tribunal, Pesuña, y Panduro, bachiller y regidor respectivamente, con la ceremonia que corresponde al saludo protocolario, al que contesta del mismo modo cada candidato ${ }^{31}$. En cuanto comienza la prueba, vuesas mercedes deja paso a un vos que suspende la gravedad y el cumplimiento, conforme a las indicaciones de Correas:

\begin{tabular}{|c|c|}
\hline BACHILleR PesuÑa. & Bien venidos \\
\hline BERROCAL. & Bien hallados \\
\hline $\begin{array}{l}\text { vuesas mercedes sean. } \\
\text { REGIDOR PANDURO. } \\
\text { que asientos sobran }[\ldots]\end{array}$ & Acomódense, \\
\hline
\end{tabular}

La presencia de variantes formales de vuestra merced es excepcional, e informa de la condición social de los hablantes. Cervantes reserva voacé para el intercambio entre dos rufianes, Chiquiznaque y Trampagos. Voacé, difundida, como otras formas, entre gentes de baja extracción social ${ }^{32}$, comparte contexto con una retahíla de «excesos» verbales (entumbe, encubra, trasponga, sombra bayetuna...) mezclados con voces vulgares y de germanía (so, garlado, tólogo), elementos que componen un discurso de cortesía paródico, y que contribuyen a la caracterización de los personajes:

\footnotetext{
ChiquiznaQue. Mi so Trampagos, ¿es posible sea

voacé tan enemigo mortal suyo

que se entumbe, se encubra y se trasponga

debajo desa sombra bayetuna

el sol hampesco? So Trampagos, basta

tanto gemir, tantos suspiros bastan.

Trueque voacé las lágrimas corrientes
}

31. Además de estas fórmulas de saludo (Baras 2012, 38, notas 125-127), el editor anota otras manifestaciones corteses (verbales y no verbales), como la expresión «¿qué es lo que vuesa merced manda?» que emplea Cristina en El vizcaíno fingido (Baras 2012, 72, nota 30) o la inclinación que se dedica a los regidores de Daganzo («Reverencia os hace el cuerpo»), empleada en ese contexto con doble sentido (Baras 2012, 44, nota 258).

32. Lapesa (2000, 319-320) considera las formas voarced, voacé, vucé, vuested, vosted, vusted propias de valentones, criadas y lacayos. Véase Del Barrio (1997, 358-362) sobre la presencia de estas formas en la Segunda parte del Quijote, y Medina Morales (2004) sobre variantes y distribución social. Respecto de la variante uste(d) y la «plebeyez» que le atribuye Lapesa (2000, 320), Sáez Rivera (2006, 2907-2908) la excluye de la supuesta chabacanería, y Pérez-Salazar (2018, 114-115) aporta este dato: usté es la variante que utiliza Pedro Crespo en El Alcalde de Zalamea de Calderón; Crespo es villano, pero rico, alcalde y hombre modélico. 
en limosnas y en misas y oraciones

por la gran Pericona, que Dios haya [...]

TRAMPAGOS. Voacé ha garlado como un tólogo,

mi señor Chiquiznaque (Rufián, 16, vv. 25-35).

\subsection{La falsa cortesía}

Si el valor respetuoso de las fórmulas que contienen merced reside en el significado encarecedor del sustantivo, el empleo de otros sustantivos y adjetivos que denotan o ponderan virtudes, o de cualquier recurso que refuerce la imagen positiva del otro deberá vincularse, en principio, con la voluntad de ser cortés. En los entremeses, las peculiares relaciones entre los personajes, y los enredos, que, a menudo, ocultan algún fingimiento o persiguen un fin perverso, favorecen el uso (y el abuso) de formas deferentes (convencionales y no convencionales) cuya finalidad no es la armonía, sino más bien la adulación, y con ella la manipulación del adversario. Las estrategias corteses sirven, por tanto, para seducir al interlocutor y obtener algún beneficio (Álvarez y Espar 2002) $)^{33}$.

Los recursos verbales que utiliza el comediante Chanfalla frente a las autoridades locales en El retablo de las maravillas forman parte de su plan para urdir un engaño. Además del tratamiento vuesa merced y la fórmula reverente besar las manos -como explica Guevara (1521-1543, II, 51), «el estilo de la corte es decirse unos a otros «beso las manos de vuestra merced»-, el comediante recurre a la multiplicación de estrategias: la que consiste en declarar su propia torpeza (indicadora de modestia) y la retahíla de halagos (con preferencia por voces polisílabas: peripatética y anchurosa presencia) que ensalzan la imagen de su interlocutor:

Chanfalla. Beso a vuesas mercedes las manos. ¿Quién de vuesas mercedes es el Gobernador deste pueblo?

GOBERNADOR. Yo soy el Gobernador. ¿Qué es lo que queréis, buen hombre? Chanfalla. A tener yo dos onzas de entendimiento, hubiera echado de ver que esa peripatética y anchurosa presencia no podía ser de otro que del dignísimo Gobernador deste honrado pueblo (Retablo, 88-89).

La falsa cortesía preside también el encuentro entre el zapatero Juan Juncos y el soldado en La guarda cuidadosa. El soldado envuelve su engaño en una reverencia excesiva: obsérvense la repetición constante de vuesa merced (tratamiento que no se emplearía con un inferior que no

33. A las nociones de poder y fuerza, imagen y territorio que condicionan la interacción comunicativa, añaden estas autoras la de manipulación. La manipulación se realiza mediante determinadas estrategias, como la atenuación. Cabe pensar que, en la adulación, se manipulan las estrategias que minimizan el poder del hablante o preservan la imagen del oyente con la intención de seducir; eso sí, en este caso, el objetivo es perverso. 
fuera distinguido, ver nota 29) y del sustantivo merced $^{34}$; la interrogación y la negación que aminoran la petición; el verbo en condicional... Juan Juncos, zapatero y «pobre oficial», pero astuto, escapa, él sí, cortésmente, con el tratamiento que corresponde a su interlocutor por rango social, y con otros recursos (además de utilizar vuesa merced, declara su condición social y la voluntad de no resultar descortés) que le sirven para atenuar el rechazo:

SOLDADO. Señor bueno, ¿busca vuesa merced algo en esta casa?

ZAPATERO. Sí busco [...]

SOLDADO. ¿No me haría vuesa merced una merced, que sería para mí muy grande, y es que me fiase estas chinelas, dándole yo prendas que lo valiesen, hasta desde aquí a dos días, que espero tener dineros en abundancia? ZAPATERO. Sí haré, por cierto. Venga la prenda, que como soy pobre oficial, no puedo fiar a nadie.

SOLDADO. Yo le daré a vuesa merced un mondadientes que le estimo en mucho, y no le dejaré por un escudo. ¿Dónde tiene vuesa merced la tienda, para que vaya a quitarle?

ZAPATERO. En la calle Mayor, en un poste de aquellos, y llámome Juan Juncos.

SoldADO. Pues, señor Juan Juncos, el mondadientes es este, y estímele vuesa merced en mucho, porque es mío [...]

ZAPATERO. Aunque zapatero, no soy tan descortés que tengo de despojar a vuesa merced de sus joyas y preseas. Vuesa merced se quede con ellas, que yo me quedaré con mis chinelas, que es lo que me está más a cuento (Guarda, 58-59).

Solórzano y Cristina, cortesanos, protagonistas de El vizcaíno fingido, usan y abusan de recursos que encarecen la imagen del otro, recursos que contrastan con el propósito de aquel y la condición social de esta, de los que el público está oportunamente informado: Cristina es una buscona y Solórzano está urdiendo un plan para engañarla. Si vuesa merced era, como explica Covarrubias -y sabrían sus contemporáneos- «común a cualquier hombre honrado» (1611, s. v.), su empleo en este caso resultaría especialmente cómico. Al tratamiento se unen también en este pasaje las estrategias de atenuación (por parte de Solórzano: perdone el atrevimiento; hablaré con verdad) y los halagos (por parte de ambos: la buena presencia de vuesa merced; su hermosura; la más discreta de la corte) $)^{35}$ :

34. Ly $(1981,56)$ señala el efecto que provocaba en el siglo XVII la repetición abusiva de la forma merced, a la que se refería Oudin, observador francés de las costumbres españolas: "Car il n'est pas toujours à propos de le répéter de même qu'en écrivant n'est pas très habile d'en user trop souvent».

35. Haverkate (1994, cap. 8) expone las estrategias de mitigación que se emplean en actos de habla no corteses. 
SOLÓRZANO. Vuesa merced perdone el atrevimiento, que la ocasión hace al ladrón. Hallé la puerta abierta y entreme, dándome ánimo al entrarme venir a servir a vuesa merced, y no con palabras, sino con obras.

CRISTINA. De la buena presencia de vuesa merced no se puede esperar sino que han de ser buenas sus palabras y sus obras. Diga vuesa merced lo que quisiere, que la señora doña Brígida es tan mi amiga que es otra yo misma. SOLÓRZANO. Con ese seguro y con esa licencia hablaré con verdad. Y con verdad, señora, soy un cortesano a quien vuesa merced no conoce.

CRISTINA. Así es la verdad.

SOLÓRZANO. Y ha muchos días que deseo servir a vuesa merced, obligado a ello de su hermosura, buenas partes y mejor término [...] Vuesa merced habla discretísimamente, y no en balde tiene vuesa merced fama de la más discreta dama de la corte (Vizcaíno, 72-74).

Falsos, igualmente, son los halagos que le dedica en presencia Brígida a Cristina -ambas busconas- en la obra, a juzgar por el modo en que la ha descrito antes en ausencia:

BRíGIDA. También le dije como vas muy limpia, muy linda y muy agraciada, y que toda eras ámbar, almizcle y algalia entre algodones.

CRISTINA. Ya yo sé, amiga, que tienes muy buenas ausencias ${ }^{36}$ (Vizcaíno, 79).

BRÍGIDA. Que en verdad no soy para desechar, y que tengo yo tan buenas entradas y salidas en mi casa como la señora doña Cristina. Que a no temer que nos oyera alguna, le dijera yo al señor Solórzano más de cuatro tachas suyas: que sepa que tiene las tetas como dos alforjas vacías, y que no le huele muy bien el aliento, porque se afeita mucho. Y con todo eso, la buscan, solicitan y quieren. Que estoy por arañarme esta cara, más de rabia que de envidia, porque no hay quien me dé la mano, entre tantos que me dan del pie. En fin, la ventura de las feas (Vizcaíno, 78).

Lo mismo cabe afirmar de las alabanzas y fórmulas corteses que se intercambian los esposos Leonarda y Pancracio (La cueva de Salamanca) en su despedida, que de inmediato (al salir Pancracio de la escena) se convierten en maldiciones:

LEONARDA. No hay sino tener paciencia, bien mío. Cuanto más os detuviéredes, más dilatáis mi contento $[\ldots]$

PANCRACIO. Quedad en paz, lumbre destos ojos, los cuales no verán cosa que les dé placer hasta volveros a ver.

(Éntrase Pancracio)

LEONARDA. ¡Allá darás, rayo, en casa de Ana Díaz! Vayas y no vuelvas; la ida del humo (Cueva, 104-105).

36. Estos elogios tienen, por cierto, doble sentido; como anota el editor, ámbar, almizcle y algalia son perfumes que proceden de las excrecencias de animales. En cuanto a las «ausencias», Cristina sabe que, en su ausencia, Brígida no ha dejado de criticarla. La frase tener buenas o malas ausencias ('hablar bien o mal de alguien cuando no está presente') se recoge en la edición del Diccionario académico de 1770 (consultado a través del NTLLE). 
Al comportamiento verbal falsamente cortés que Cervantes construye para el intercambio entre sus personajes, cabe añadir el empleo irónico de los términos cortesía y cortés, cuyo significado, como ocurre en los pasajes que siguen, han de interpretar los lectores o espectadores ${ }^{37}$ :

CRISTINA. ¿Cómo es el nombre de vuesa merced, por su vida?

SolórZANO. Don Esteban de Solórzano me suelen llamar en mi casa. Pero ¿por qué me lo pregunta vuesa merced?

CRISTINA. Por acabar de echar el sello a su mucha verdad y cortesía (Vizcaíno, 77).

CRISTINA. ¡Ay, qué bien criados, qué corteses! Nunca medre yo si todos los diablos son como estos... (Cueva, 116).

\subsection{La descortesía en los entremeses}

Mencionaba antes la recurrencia de situaciones de conflicto en estas obras, de las que surgen múltiples enfrentamientos verbales; mucho más frecuentes que las estrategias que buscan el equilibro son los comportamientos que desprecian o dañan la imagen del otro $^{38}$. Si la cortesía, verdadera o falsa, despliega un buen número de recursos verbales, las actuaciones en las que se busca desprestigiar o herir al otro o impedir el ejercicio de su voluntad los superan ampliamente; es, de hecho, en las disputas verbales donde Cervantes encuentra un filón para explotar el material lingüístico ${ }^{39}$.

Puede decirse que no hay individuo que escape en estas obras a un enfrentamiento verbal, con la única excepción del juez de los divorcios, cuyo papel consiste en presenciar conflictos y apaciguar los ánimos. Por debajo de este personaje, hombres y mujeres de cualquier edad, estamento y dedicación protagonizan encuentros que favorecen la presencia combinada de recursos lingüísticos que atentan contra la imagen del otro: desprecios, reproches, amenazas, insultos, maldiciones, juramentos, actos impositivos... ${ }^{40}$. No debe olvidarse, sin embargo, la finalidad lúdica de estas

37. En el primer testimonio, «la mucha verdad y cortesía» contrasta con la presencia de don y de, indicadores de alcurnia de caballero, que en este caso es imaginaria (Baras 2012, 77, nota 64); en el segundo, el adjetivo cortés se aplica al sacristán y al barbero, que Cristina califica de muy honrados y muy hombres de bien, pero que, como sabe el público, son los dos diablos, los «demonicos humanos» (Baras 2012, 115, nota 105).

38. Culpeper (1996, 355-358) interpreta la descortesía como antítesis de la cortesía, y distingue la descortesía real y la fingida.

39. Véase Fernández Álvarez $(1984,757-765)$ sobre la visión que Cervantes presenta de la sociedad de su tiempo: el matrimonio, la justicia, los ladrones y rufianes, la brujería, etc.

40. Remito a Haverkate $(2001,137-141)$ para un análisis de la cortesía en el Quijote; el autor distingue actos expresivos (que afectan a la imagen del interlocutor) y actos realizativos (como los juramentos, que afectan a la imagen del hablante). 
piezas, que convierte las agresiones en un recurso para la distensión y la risa del espectador ${ }^{41}$.

Como se puede apreciar en los testimonios que siguen, es habitual que se acumulen en un solo intercambio varias formas de agresión verbal. Así sucede entre las prostitutas Repulida, Pizpita y Mostrenca (El rufián viudo):

RePUlida. ¿Contra mí la Pizpita y la Mostrenca?

¿En tela quieres competir conmigo, culebrilla de alambre; y tú, pazguata?

PizPITA. ¡Por vida de los huesos de mi abuela, doña Maribobales, mondaníspolas, que no la estimo en un feluz morisco! ¿Han visto el ángel tonto almidonado como quiere empinarse sobre todas $[\ldots]$ ?

REPULIDA. Aparta, tomaré yo la venganza rasgando con mis manos pecadoras la cara de membrillo cuartanario [...] PIZPITA. ¡Déjala venga, déjala que llegue esa cara de masa mal sobada! (Rufián, 23-24, vv. 185-192 y 202-207).

Entre Rana (aldeano, candidato a alcalde) y el sacristán (La elección de los alcaldes de Daganzo):

RANA. Dime, desventurado, ¿qué demonio se revistió en tu lengua? ¿Quién te mete a ti en reprehender a la justicia?

¿Has tú de gobernar a la república?

Métete en tus campanas y en tu oficio.

Deja a los que gobiernan, que ellos saben

lo que han de hacer mejor que no nosotros [...]

[Lo mantean]

SACRISTÁn. ¡Vive Dios, si me enojo, que bonito

soy yo para estas burlas! ¡Por san Pedro

que están descomulgados todos cuantos

han tocado los pelos de la manta! (Alcaldes, 48, vv. 339-355).

\section{Entre el soldado y el sacristán (La guarda cuidadosa):}

SoldAdO. Pues ven acá, sotasacristán de Satanás.

SACRISTÁn. Pues voy allá, caballo de Ginebra.

SOLDADO. Bueno: sota y caballo; no falta sino el rey para tomar las manos ['abrir el juego']. Ven acá, digo otra vez, ¿y tú no sabes, Pasillas (que pasado te vea yo con un chuzo), que Cristinica es prenda mía?

41. Albuixec (2001) defiende el empleo carnavalesco o festivo de las agresiones verbales en $L a$ Celestina, y se refiere al valor terapéutico del insulto. Oteiza (2013, 178-183), que describe la distensión y comicidad de las ofensas en el teatro de Tirso de Molina, añade que son un cauce para el ingenio y la experimentación lingüística. 
SACRISTÁn. ¿Y tú no sabes, pulpo vestido, que esa prenda la tengo yo rematada, que está por sus cabales y por mía?

SOLDADO. ¡Vive Dios que te dé mil cuchilladas y que te haga la cabeza pedazos!

SACRISTÁn. Con las que le cuelgan desas calzas y con los dese vestido se podrá entretener, sin que se meta con los de mi cabeza [...]

SOLDADO. Ven acá, motilón arrastrado, respóndeme a esto que preguntarte quiero (Guarda, 51-53).

A la vista de estos tres diálogos, en los que participan, respectivamente, tres prostitutas, un aldeano y un sacristán, y un soldado y un sacristán, cabe afirmar que el comportamiento verbal descortés no conoce condición ni barreras sociales: sucede entre iguales y desiguales (de arriba abajo y de abajo arriba), y que la condición social no distingue contenidos o formas de expresión.

Como se aprecia ya en estos pasajes, la descortesía verbal adquiere un largo alcance, tanto por su recurrencia (puede ser incluso el sustento de la acción dramática, como en La guarda cuidadosa), como por la variedad de recursos que pone en funcionamiento. Además de los modos no verbales - como «hacer cocos» con el rabo de zorra atado a un palo (Guarda) o mantear

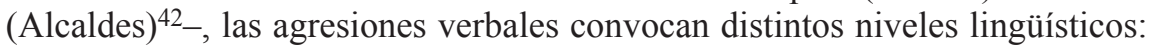
suprasegmental (a la entonación reflejada en los signos de exclamación habría que añadir todas las posibilidades que ofrecería la realización oral, aunque no sea posible analizarlas aquí); léxico (derivación y composición, metáforas); y gramatical (tratamiento en tercera persona; demostrativos (Baras 2012, 279280); imperativos; cuantificadores; adjetivos...), recursos que analizo más adelante. Esta variedad se corresponde con los múltiples modos de ser descortés, que, como se ha visto en los testimonios, suelen concurrir en una sola intervención. Es habitual que los enfrentamientos no pasen de las palabras, salvo cuando la intensidad de las emociones provoca la pérdida del control, como sucede en el encuentro entre los sacristanes y el soldado en La guarda cuidadosa, presidido por los $\operatorname{celos}^{43}$, y en el pasaje final en El retablo de las maravillas, en el que la reiteración de la burla al furrier -en relación con su origen converso- desencadena en él la ira ${ }^{44}$.

Describo a continuación las agresiones verbales que adquieren mayor presencia en los entremeses - desprecios, insultos y pullas ${ }^{45}$, amenazas y mal-

42. Baras (2012, 47, notas 327-332) explica que al sacristán lo mantean por insolente (como a Sancho en la venta), y añade que el manteo era un castigo habitual en relatos, con precedente «en cierto Entremés de Horozco», donde se mantea a un fraile poco antes del desenlace. Respecto de hacer cocos, gesto que se realizaba para causar miedo (Baras 2012, 64, nota 104), lo recoge Franciosini en su diccionario español-italiano, en 1620, s. v. hacer.

43. Anota el editor que los dos personajes protagonistas, el soldado y el sacristán, son tipos cómicos que representan lo más bajo de su oficio dentro del ejército y la iglesia. El propio Cervantes los describe como un soldado a lo pícaro y un muy mal sacristán (Baras 2012, 51).

44. Sobre descortesía y estados anímicos en el Quijote, véase Frago (2005, cap. 3).

45. El término pulla es el empleado, en el tiempo en que fueron escritas estas obras, para referirse a la palabra que «se siente y escuece», como explica el diccionario de Francisco del Rosal (1611, s. v.), o a una 'expresión aguda o picante o sucia o deshonesta', según la primera edición del diccio- 
diciones- y los recursos que Cervantes pone en boca de sus personajes para los comportamientos descorteses.

Un modo habitual de mostrar desprecio o indiferencia al interlocutor consiste en convertirlo en tercera persona, lo cual supone despojarlo de su condición de persona del discurso; el valor despectivo se enfatiza siempre, en estas piezas, con el auxilio de un demostrativo:

SOLDADO. ¿Han visto la desvergüenza deste bellaco que me viene a hacer cocos con un rabo de zorra, no habiéndome espantado ni atemorizado tiros mayores que el de Dío, que está en Lisboa? (Guarda, 63).

CAÑIZARES. Señora Hortigosa, abrevie y váyase, y no se esté agora juzgando almas ajenas $[\ldots]$

CAÑIZARES. ¡Aquí de Dios! ¿Que no será posible que me deje esta vecina? ¡Hortigosa, o diablo, o vecina, o lo que eres, vete con Dios y déjame en mi casa! (Viejo, 129-130).

Si descortés es convertir al interlocutor en tercera persona, no lo es menos proyectar descalificaciones hacia una tercera persona presente en la situación comunicativa. Esta circunstancia es constante en El juez de los divorcios, donde cada compareciente se dirige al juez en presencia de su cónyuge, y manifiesta sus quejas mediante recursos que ponen a este en evidencia, y que suelen recibir una amonestación de la autoridad. En estos casos, además del demostrativo, en la alusión al destinatario participa un improperio:

\footnotetext{
MARIANA. Señor, ¡divorcio, divorcio y más divorcio, y otras mil veces divorcio!

JUEZ. ¿De quién o por qué, señora?

MARIANA. ¿De quién? Deste viejo que está presente.

JUEZ. ¿Por qué?

MARIANA. Porque no puedo sufrir sus impertinencias, ni estar contino atenta a curar todas sus enfermedades, que son sin número [...] Muy buen dote llevé al poder desta espuerta de huesos que me tiene consumidos los días de la vida [...] Mire, mire los surcos que tengo por este rostro, de las lágrimas que derramo cada día por verme casada con esta anotomía (Juez, 3-4).

D. ${ }^{a}$ Guiomar. ¡Bendito sea Dios, que se me ha cumplido el deseo que tenía de verme ante la presencia de vuesa merced, a quien suplico, cuan encarecidamente puedo, sea servido de descasarme deste!

JUEZ. ¿Qué cosa es deste? ¿No tiene otro nombre? Bien fuera que dijérades siquiera deste hombre.

D. ${ }^{a}$ Guiomar. Si él fuera hombre, no procurara yo descasarme.

Juez. Pues ¿qué es?

D. ${ }^{a}$ Guiomar. Un leño $[\ldots]$
}

nario académico (Aut., s. v.) (consultados desde el NTLLE). El término insulto se aplicaba a un acometimiento violento para causar daño (Aut., s. v.). Como se verá, predominan las agudezas con vocación cómica. 
PROCURADOR. Hablad más comedido, señora, y relatad vuestro negocio sin improperios de vuestro marido. [...]

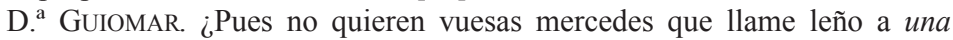
estatua que no tiene más acciones que un madero? (Juez, 7-8).

Como ya se aprecia en los testimonios expuestos hasta aquí, los insultos son recurso habitual en los intercambios de los entremeses, y con frecuencia se acumulan en un turno de palabra mediante distintos procedimientos: obsérvese que las ofensas admiten explicaciones pormenorizadas y emumeraciones; que se coordinan elementos de ámbitos conceptuales distantes (por ejemplo, manirrota y dormilona); que se crean tautologías (insolente y atrevido además), o se combinan términos que el contexto transforma en sinónimos (Hortigosa, o diablo o vecina $)^{46}$ :

SoldADO. Por esto solo merecía ser querida esta mujer. Pero debajo deste pundonor tiene encubierta la más mala condición de la tierra: pide celos sin causa, grita sin porqué, presume sin hacienda y, como me ve pobre, no me estima en el baile del rey Perico [...] ¿Qué se me da a mí que seáis casta con vos misma, puesto que se me da mucho, si os descuidáis de que lo sea vuestra criada, y si andáis siempre rostrituerta, enojada, celosa, pensativa, manirrota, dormilona, perezosa, pendenciera, gruñidora, con otras insolencias deste jaez, que bastan a consumir las vidas de docientos maridos? (Juez, 10).

BACHILlER. Traigan aquí una manta, que por Cristo, que se ha de mantear este bellaco, necio, desvergonzado e insolente, y atrevido además (Daganzo, 47, vv. 328-331).

CAÑIZARES. ¡Aquí de Dios! ¿Que no será posible que me deje esta vecina? ¡Hortigosa, o diablo, o vecina, o lo que eres, vete con Dios y déjame en mi casa! (Viejo, 130).

En los casi setenta insultos que encuentro en estas piezas, no es apenas relevante la diferencia en el cómputo de los destinados a hombres y a mujeres (38 frente a 29, dato este que, teniendo en cuenta la proporción de personajes masculinos y femeninos, lleva a concluir que ellas reciben proporcionalmente muchos más, de los que, eso sí, buena parte proceden de otras mujeres). Son también similares los ámbitos conceptuales, con algunas diferencias que expongo a continuación.

Los que se dirigen a los protagonistas masculinos se refieren a rasgos asociados a la vejez, físicos o relativos a su impotencia (espuerta de huesos,

46. Estos recursos con vocación cómica hacen pensar en la finalidad de muchas de las agresiones verbales en los entremeses cervantinos, la misma que se ha descrito, por ejemplo, para La Celestina: Albuixec (2001), que analiza insultos, pullas y vituperios, recuerda que existía en España el juego verbal popular que consistía en «echarse pullas». Luque, Pamies y Manjón $(2017,8)$ atribuyen al insulto una función catártica. 
anotomía, viejo podrido, viejo clueco, tan potroso como celoso, leño, estatua que no tiene más acciones que un madero); a la pobreza -y, con frecuencia, a sus consecuencias en la apariencia externa- (desventurado, pulpo vestido); a las cualidades mentales (mentecato, un poco burro); a la ignorancia (necio); al origen (hideputa); a la religión, con preferencia por la condición de converso (fariseo, canalla barretina, so escriba); a los comportamientos delictivos (ladrones), inmorales (bellaco, hi de malicias, desvergonzado, sabandijas, cobarde) o inconvenientes (impertinente, insolente, atrevido, boca de lobo, lengua de escorpión, bárbaro, salvaje), y a la condición social (sotasacristán de Satanás, motilón arrastrado).

Los insultos destinados a mujeres alcanzan más características en lo que respecta al aspecto externo y la higiene (rostrituerta, cara de membrillo cuartanario, cara de masa mal sobada, tiene las tetas como dos alforjas vacías, fea, no le huele muy bien el aliento, sucia). Se refieren también a cualidades mentales (boba, pazguata, maribobales); al carácter y comportamiento (enfadosa, mudables, antojadizas, celosa, enojada, pendenciera, gruñidora, soberbia, manirrota, dormilona, perezosa, moscovitas -'que quieren mosca o dinero'-, diablo, deshonesta); al origen y limpieza de sangre (hideputa, bellaca jodía).

De acuerdo con la finalidad lúdica de los entremeses, predominan -y así se observa en esta relación- las descalificaciones relacionadas con el aspecto externo y los comportamientos no delictivos, y, por tanto, las burlas menos dañinas. Destaca, asimismo, la variedad de recursos léxicos, sintácticos y semánticos que Cervantes acumula en las disputas verbales. Junto con los neologismos creados mediante derivación (moscovitas), composición (mondaníspolas), parasíntesis (maribobales; atontoneleada); las metáforas (culebrilla de alambre; pulpo vestido; motilón arrastrado; silo de malicias; moscovitas); o los juegos de palabras (bellaca jodía) ${ }^{47}$, se observa una tendencia constante a la intensificación mediante procedimientos diversos, que a menudo se combinan (prefijación, superlativos, reiteración y estructuras comparativas y consecutivas, entre otros): viejo y reviejo, y más que viejo, y no me puedo hartar de decille viejo; grandísimos bellacos; tan potroso como celoso; la más mala condición de la tierra; con más ungüentos y medicinas en el aposento que si fuera una botica; tan soberbia y de tan mala condición que nadie llega a su tabla con quien no riña...

Algunas formas de insultar más creativas evitan la mención directa del vicio o defecto; las alusiones indirectas adoptan la forma de estructuras oracionales complejas y compuestas, como las que tienen que ver con la pequeñez de Rabelín - personaje en el que Chanfalla proyecta sus burlas en varias ocasiones-, la costumbre de beber de Trampagos o la ignorancia y la debilidad de los regidores de Daganzo:

47. A excepción de moscovitas, los que incluyo en esta relación de neologismos solo están documentados en las piezas cervantinas, según datos del CORDE, de modo que pueden ser creaciones originales del autor. 
CHIRINOs [a Rabelín]. Cuatro cuerpos de los vuestros no harán un tercio, cuanto más una carga. Si no sois más gran músico que grande, medrados estamos.

RABELín. Ello dirá. Que en verdad que me han escrito para entrar en una compañía de partes, por chico que soy.

Chanfalla. Si os han de dar la parte a medida del cuerpo, casi será invisible (Retablo, 88).

Trampagos. Vestime este capuz, mis dos lanternas convertí en alquitaras.

VADEMÉCUM. ¿De aguardiente?

Trampagos. Pues itanto cuelo yo, hi de malicias?

VADEMÉCUM. A cuatro lavanderas de la puente

puede dar quince y falta en la colambre;

¡miren qué ha de llorar, sino agua ardiente! (Rufián, 22, vv. 165-170).

Uno [a los regidores]. Parece que os hizo el cielo,

el cielo, digo, estrellado,

Sansones para las letras,

y para las fuerzas, Bártulos (Alcaldes, 44, vv. 266-269).

A los insultos les siguen en frecuencia las amenazas, que aparecen precedidas de advertencias o de órdenes categóricas (y vinculadas a su cumplimiento), se refuerzan con juramentos y concurren siempre con otras manifestaciones de la agresión verbal. Se producen en situaciones de desigualdad social (de superior a inferior) y entre iguales de clase acomodada, con la diferencia de que solo en este último caso la amenaza recibe respuesta:

SOLDADO. Y séale aviso que por cuatro días no vuelva a llegar a esta puerta ni por lumbre, que le romperé las costillas a coces.

Mozo. Ni aun volveré en este mes, si es que me acuerdo. No tome vuesa merced pesadumbre, que ya me voy $[\ldots]$

SOLDADO. Tranzaderas, o como os llamáis, ¿conocéis aquella doncella que os llamó desde la ventana?

UNO. Sí conozco. Pero ¿por qué me lo pregunta vuesa merced?

SOLDADO. ¿No tiene muy buen rostro y muy buena gracia?

UnO. A mí así me lo parece.

SoldADO. Pues también me parece a mí que no entre dentro desa casa.

Si no, ipor Dios que he de molelle los huesos, sin dejarle ninguno sano! (Guarda, 56-57).

RABELín. Señor alcalde, no tome conmigo la hincha ['antipatía'], que yo toco como Dios ha sido servido de enseñarme.

BENITO. ¿Dios te había de enseñar, sabandija? ¡Métete tras la manta! ¡Si no, por Dios que te arroje este banco! (Retablo, 97).

Benito. Ahora yo conozco bien a Tontonelo, y sé que vos y él sois unos grandísimos bellacos, no perdonando al músico. Y mirá que os mando que mandéis a Tontonelo no tenga atrevimiento de enviar estos hombres de 
armas, que le haré dar docientos azotes en las espaldas que se vean unos a otros (Retablo, 99).

Benito. ¿Que todavía ha salido con la suya Tontonelo? ¡Pues yo os voto a tal, autor de humos y de embelecos, que me lo habéis de pagar! (Retablo, 100).

BERROCAL. Solo digo

que no se me malogre mi justicia, que echaré el bodegón por la ventana.

BACHILlER. Amenazas aquí, por vida mía, mi señor Berrocal, que valen poco (Alcaldes, 41, vv. 185-189).

Como se observa en los casos que preceden y en los que siguen, los males que se anuncian consisten en ajustes de cuentas genéricos, daños en los bienes, daños físicos - con indicaciones precisas-, la muerte y el infierno, e incluso la excomunión. Cabe destacar que las amenazas más graves surgen en momentos de ira -es el caso, antes mencionado, del sacristán manteado en Los alcaldes de Daganzo o el del furrier acusado de judío en El retablo de las maravillas - o bien bajo el dominio de los celos, como sucede reiteradamente en La guarda cuidadosa:

SACRISTÁN. ¡Va de veras, por Dios!

¡Vive Dios, si me enojo, que bonito

soy yo para estas burlas! ;Por san Pedro,

que están descomulgados todos cuantos

han tocado los pelos de la manta! (Daganzo, 48, vv. 351-355).

JUAN. ¡Dellos es, dellos el señor furrier, dellos es!

FURRIER. ¡Soy de la mala puta que los parió! ¡Y por Dios vivo, que si echo mano a la espada, que los haga salir por las ventanas, que no por la puerta! CAPACHO. Basta. ¡De ex ilis es!

BEnito. Basta. ¡Dellos es, pues no vee nada!

FURRIER. ¡Canalla barretina! ¡Si otra vez me dicen que soy dellos, no les dejaré un hueso sano! (Retablo, 101).

Soldado. ;Vive Dios que te dé mil cuchilladas y que te haga la cabeza pedazos!

SACRISTÁn. Con las que le cuelgan desas calzas y con los dese vestido se podrá entretener, sin que se meta con los de mi cabeza (Guarda, 52).

SoldADO. Pues señor Andrés, esté en lo que quiero decirle: tome este cuarto de a ocho, y haga cuenta que va pagado por cuatro días de la limosna que le dan en esta casa y suele recebir por mano de Cristina, y váyase con Dios. Y séale aviso que por cuatro días no vuelva a llegar a esta puerta ni por lumbre, que le romperé las costillas a coces (Guarda, 56).

SOLDADO. ¡Sacristanes falsos, voto a tal que os tengo de horadar, aunque tengáis más órdenes que un ceremonial! [...] ¡Tente, rabo, y tente, tapadorcillo, no acabéis de despertar mi cólera, que si la acabo de despertar, os mataré, y os comeré, y os arrojaré por la puerta falsa dos leguas más allá del infierno! (Guarda, 63-64). 
Menos frecuentes que insultos y amenazas, las maldiciones expresan deseos perversos, aunque, con frecuencia, la comicidad del contexto aminora la gravedad de la imprecación:

PizPITA. Desollado le viesen ya mis lumbres

de aquel pellejo lóbrego y escuro ${ }^{48}$ (Rufián, 20, vv. 130-131).

Benito Repollo. Quítenme de allí aquel músico. Si no, voto a Dios que me vaya sin ver más figura. ¡Válgate el diablo por músico aduendado, y qué hace de menudear sin cítola y sin son! (Retablo, 97).

VADEMÉCUM. No tengo taza.

Trampagos. Dios te la depare.

El cuerno de orinar no está estrenado.

Tráele, que te maldiga el Cielo santo,

que eres bastante a deshonrar un duque (Rufián, 26, vv. 260-263).

Bajo la apariencia de una maldición se transmiten también contenidos no optativos. En los testimonios que siguen, Mariana emplea una expresión maldiciente para expresar rechazo categórico a la propuesta de su esposo de que cada uno de ellos se retire a un monasterio; Benito, enfadado, insulta a Chirinos; doña Lorenza, que sufre los celos sin límite de su esposo, expresa su estado anímico de desesperación:

MARIANA. ¡Malos años! ¡Bonica soy yo para estar encerrada! (Juez, 6).

Chanfalla. Séanme testigos que me amenaza el Alcalde.

Chirinos. Séanme testigos que dice el Alcalde que lo que manda Su Majestad lo manda el sabio Tontonelo.

Benito. Atontoneleada te vean mis ojos, plega a Dios todopoderoso (Retablo, 100).

DoÑa LoREnZA. Que malditos sean sus dineros, fuera de las cruces, malditas sus joyas, malditas sus galas, y maldito todo cuanto me da y promete (Viejo, 119).

\section{FINAL}

La reconstrucción del pasado sociolingüístico -en este caso, el español del siglo XVII- ha de partir necesariamente de fuentes escritas (Conde Silvestre 2007, 42-46). Para la elaboración de este trabajo, cuyo objetivo consiste en revisar los comportamientos verbales relacionados con la (des)cortesía, se han

48. Pizpita quiere ver desnudo a Trampagos, no desollado. 
analizado las expresiones corteses y descorteses en los ocho entremeses de Miguel de Cervantes.

No parece descabellado afirmar que los entremeses de Cervantes desprenden información sobre la lengua y la sociedad de su tiempo ${ }^{49}$. Desfila por estas piezas una generosa representación social -con notable predominio de las clases populares-, y con ella una parte de los usos lingüísticos vigentes a comienzos del siglo XVII ${ }^{50}$, al menos en lo que respecta a las manifestaciones de la (des)cortesía. Cervantes construye los intercambios a partir de su observación de la realidad, pero manipula las formas expresivas para construir un diálogo cómico.

El empleo de la fórmula vuesa merced se ajusta rigurosamente a las pautas (sociales y situacionales) que anotan gramáticos y tratadistas. De acuerdo también con la distribución social de las variantes, la forma voacé (que coexiste con otras peculiaridades expresivas) se reserva para el intercambio entre rufianes. De este modo, parte de la información que desprenden los entremeses tiene que ver con la relación entre variantes o estilos y estratificación social ${ }^{51}$.

Las expresiones corteses no codificadas, compatibles con vuesa merced, pero también con vos, suceden sobre todo en las relaciones asimétricas, y su presencia aparece condicionada por la formalidad y la finalidad del intercambio verbal.

La acumulación de situaciones conflictivas («borrascas y tormentas», según las describe el Bachiller de Daganzo) favorece una notable presencia de la falsa cortesía, componente esencial en los enredos basados en engaños, manipulaciones y burlas. Pero si hay un rasgo característico de estas pequeñas obras es el alcance de la descortesía, tanto en la diversidad de los modos de agresión verbal (y no verbal) como en cuanto a los recursos que pone en marcha el autor y al número de hablantes que involucra. Sean o no los que circulaban por las calles, desprecios, insultos, amenazas y maldiciones retratan la agudeza verbal que describe Baltasar Gracián (1642-1648, 323), agudeza que muestra el propio Cervantes, y que encuentra múltiples posibilidades de acumulación de recursos y de experimentación lingüística.

Las diversas realizaciones de la agresión verbal son, además, un componente esencial para la finalidad cómica de estas piezas, que viene a sumarse a otras estrategias -ironía, equívocos, disfemismos, deformación lingüística,

49. Remito a Zimic (1992, 26-31) para una descripción de las que considera «joyas cervantinas», en la que subraya la sátira y la intención moralizante, la preocupación ética y la sutileza expresiva de los entremeses, pese a las limitaciones del género.

50. Para Bustos Tovar (2006, 33-34), que considera que el personaje literario se comporta de acuerdo con la condición literaria que le otorga el autor, «cuanto más marginal sea el contexto social del personaje, más libre será en su modo de expresión».

51. Falta, en estas obras, el "intramundo quijotesco" que coexiste con el "mundo real", de donde surge un "mundo transformado" (García Gallarín 2002, 633). Así pues, la interacción verbal cortés en estas piezas parece ajustarse más a las pautas sociales de su tiempo. 
denominación de personajes...- que revelan, en última instancia, el protagonismo del lenguaje en los entremeses ${ }^{52}$.

\section{FUENTE}

Cervantes, Miguel de. 2012. Entremeses. Edición, estudio y notas de Alfredo Baras Escolá. Madrid: Biblioteca Clásica de la Real Academia Española.

\section{BIBLIOGRAFÍA CITADA}

Agostini, Amelia. 1964. «El teatro cómico de Cervantes». BRAE 44: 223-308.

Albelda Marco, Marta y María Jesús Barros García. 2018. La cortesía en la comunicación, 2. ${ }^{\text {e }}$ ed. Madrid: Arco Libros. Cuadernos de Lengua Española.

Albuixec, Lourdes. 2001. «Insultos, pullas y vituperios en Celestina». Celestinesca 25 (12): $57-68$.

Alonso, Dámaso. 1962 [1947]. «La muerte del usted». En Del Siglo de Oro a este siglo de siglas, 264-267. Madrid: Gredos.

Álvarez, Alexandra y Teresa Espar. 2002. «Cortesía y poder: un acercamiento socio-semiótico». Lengua y habla 7: 11-36.

Arellano, Ignacio. 1995. Historia del teatro español del siglo XVII. Madrid: Cátedra.

Asensio, Eugenio. 1971. Itinerario del entremés. Desde Lope de Rueda a Quiñones de Benavente. Con cinco entremeses inéditos de D. Francisco de Quevedo, 2. ${ }^{\mathrm{a}}$ ed. revisada. Madrid: Gredos.

Bañón Hernández, Antonio Miguel. 2001. «Apuntes para el estudio del tratamiento apelativo en el Siglo de Oro español». Tonos Digital. Revista Electrónica de Estudios Filológicos 1. Accesible en: <www.um.es/tonosdigital/znum1/estudios/ab0.htm>.

Baranda Leturio, Consolación y Ana Vian Herrero. 2006. «Introducción». En El personaje literario y su lengua en el siglo XVI, eds. Consolación Baranda y Ana Vian, 7-11. Madrid: Instituto Universitario Menéndez Pidal - Universidad Complutense.

Bravo, Diana y Antonio Briz, eds. 2004. Pragmática sociocultural: estudios sobre el discurso de cortesía en español. Barcelona: Ariel Lingüística.

Brown, Roger y Albert Gilman. 1960. «The pronouns of power and solidarity». En Style in Language, ed. Thomas A. Sebeok, 253-276. Cambridge MA: MIT Press.

Brown, Penelope y Stephen C. Levinson. 1987 [1978]. Politeness. Some Universals in Language Usage, 2. ${ }^{\mathrm{a}}$ ed. Cambridge University Press.

Bustos Tovar, José Jesús de. 1996. «La construcción del diálogo en los entremeses cervantinos». En En torno al teatro del Siglo de Oro, eds. José Berbel et al., 275-289. Almería: Instituto de Estudios Almerienses.

Bustos Tovar, José Jesús de. 1998. «Lengua viva y lenguaje teatral en el siglo XVI: de los pasos de Lope de Rueda a los entremeses de Cervantes». En Competencia escrita, tradiciones discursivas y variedades lingüisticas. Aspectos del español europeo y americano en los siglos XVI y XVII, eds. Wulf Oesterreicher, Eva Stoll y Andreas Wesch, 421-444. Tübingen: Gunter Narr.

52. Madroñal $(2001,190)$ destaca y describe la importancia del lenguaje en Quiñones de Benavente, y apunta que el entremés es campo abonado para las pullas. 
Bustos Tovar, José Jesús de. 2006. «Lengua común y lengua del personaje en la transición del siglo XV al XVI». En El personaje literario y su lengua en el siglo XVI, eds. Consolación Baranda y Ana Vian, 13-40. Madrid: Instituto Universitario Menéndez Pidal - Universidad Complutense.

Conde Silvestre, Juan Camilo. 2007. Sociolingüistica histórica. Madrid: Gredos.

Correas, Gonzalo. 1954 [1635]. Arte de la lengua española castellana. Edición y prólogo de Emilio Alarcos García. Madrid: CSIC. Anejo LVI de la Revista de Filología Española.

Covarrubias, Sebastián de. 2006 [1611]. Tesoro de la lengua castellana o española. Edición integral e ilustrada de Ignacio Arellano y Rafael Zafra. Madrid - Frankfurt: Iberoamericana - Vervuert.

Culpeper, Jonathan. 1996. «Towards an anatomy of impoliteness». Journal of Pragmatics 25(3): 349-367.

Del Barrio Estévez, Laura. 1997. «Vacilaciones en el sistema de tratamiento del español clásico: El Quijote, II parte». Verba. Anuario Galego de Filoloxía 24: 349-370.

Enguita Utrilla, José María. 1986. «Fórmulas de tratamiento en El Criticón». En Gracián y su época. Actas de la I Reunión de Filólogos Aragoneses, 295-316. Zaragoza: Institución Fernando el Católico.

Fernández Álvarez, Manuel. 1984. La sociedad española en el Siglo de Oro. Madrid: Editora Nacional.

Fernández Rodríguez, Mauro. 2003. «Constitución del orden social y desasosiego: pronombres de segunda persona y fórmulas de tratamiento en español». Centro Virtual Cervantes. Accesible en: <https://cvc.cervantes.es/lengua/coloquio_paris/ponencias/ pdf/cve_fernandez.pdf $>$.

Fernández Rodríguez, Mauro y Katharina Gerhalter. 2016-2017. «Pronombres de segunda persona y fórmulas de tratamiento en español. Una nueva bibliografía (1867-2016)». Linred. Lingüística en la Red 14. Accesible en: <http://www.linred.es/informacion_pdf/ LR_informacion20_20170219.pdf>.

Fontanella de Weinberg, María Beatriz. 1999. «Sistemas pronominales de tratamiento usados en el mundo hispánico». En Gramática descriptiva de la lengua española, eds. Ignacio Bosque y Violeta Demonte, I, 1400-1425. Madrid: Espasa.

Frago Gracia, Juan Antonio. 2005. «El tratamiento personal en el Quijote: del hecho sociolingüístico al recurso literario». Boletín de la Real Academia Española 85: 295-323.

Franciosini Florentin, Lorenzo. 1620. Vocabulario español-italiano, ahora nuevamente sacado a la luz [...]. Segunda parte. Roma: Juan Pablo Profillo. Accesible en: <http:// ntlle.rae.es/ntlle/SrvltGUISalirNtlle>.

Fuentes Rodríguez, Catalina. 2000. Lingüística pragmática y Análisis del discurso. Madrid: Arco Libros.

Gancedo Ruiz, Marta. 2016. «El texto dramático literario como corpus para el análisis histórico de las actividades de imagen». Textos en Proceso 2(1): 162-173.

García Gallarín, Consuelo. 2002. «Fórmulas de tratamiento en El Quijote». En Actas del $V$ Congreso Internacional de Historia de la Lengua Española, eds. María Teresa Echenique y Juan Pedro Sánchez Méndez, I, 633-644. Madrid: Gredos.

González Maestro, Jesús. 1998. «Construcción e interpretación del diálogo en los 'entremeses' de Miguel de Cervantes». En Actas del Tercer Congreso Internacional de la Asociación de Cervantistas, coord. Antonio Pablo Bernat Vistarini, 591-610. Palma: Universitat de les Illes Balears, Servei de Publicacions i Intercanvi Cientific.

Gracián, Baltasar. 1993 [1642-1648]. Agudeza y arte de ingenio. En Obras completas de Baltasar Gracián, II, ed. Emilio Blanco. Madrid: Turner.

Gracián Dantisco, Lucas. 1968 [1593]. Galateo español. Estudio preliminar, edición, notas y glosario por Margherita Morreale. Madrid: CSIC. 
Guevara, Fray Antonio de. 1950-1952 [1521-1543]. Epistolas familiares, ed. José María de Cossío. Madrid: Real Academia Española.

Haverkate, Henk. 1994. La cortesía verbal. Estudio pragmalingüistico. Madrid: Gredos.

Haverkate, Henk. 2001. «Cortesía y descortesía en los diálogos del Quijote. Análisis de la representación de las imágenes positiva y negativa de los protagonistas». Oralia, Análisis del discurso oral 4: 129-148.

Hummel, Martin, Bettina Kluge y María Eugenia Vázquez Laslop, eds. 2010. Formas y fórmulas de tratamiento en el mundo hispánico. México - Graz: El Colegio de México - Karl Franzens Universität.

Iglesias Recuero, Silvia. 2010. «Aportación a la historia de la (des)cortesía: las peticiones en el siglo XVI». En (Des)cortesía en español. Espacios teóricos y metodológicos para su estudio, eds. Franca Orletti y Laura Mariottini, 369-396. Roma - Estocolmo: Università degli Studi Roma Trè - Universidad de Estocolmo.

Kaul de Marlangeon, Silvia. 2008. «Tipología del comportamiento verbal descortés en español». En Cortesía y conversación: de lo escrito a lo oral. III Coloquio Internacional del Programa EDICE, eds. Antonio Briz et al., 254-266. Valencia: Universitat de València.

Kaul de Marlangeon, Silvia. 2017. «Tipos de descortesía verbal y emociones en contextos de cultura hispanohablante». Pragmática sociocultural/Sociocultural Pragmatics 5 (1). Accesible en: $<$ https://www.researchgate.net/publication/318191020_Tipos_de_ descortesia_verbal_y_emociones_en_contextos_de_cultura_hispanohablante $>$.

Kerbrat-Orecchioni, Catherine. 2004. «¿Es universal la cortesía?». En Pragmática sociocultural. Estudios sobre el discurso de cortesía en español, eds. Diana Bravo y Antonio Briz, 39-54. Barcelona: Ariel.

King, Jeremy. 2010. «Ceremonia y cortesía en la literatura del Siglo de Oro: un estudio de las formas de tratamiento en español». En Formas y fórmulas de tratamiento en el mundo hispánico, eds. Martin Hummel, Bettina Kluge y María Eugenia Vázquez, 531550. México: El Colegio de México.

Lapesa Melgar, Rafael. 2000 [1970]. «Personas gramaticales y tratamientos en español». En Estudios de morfosintaxis histórica del español, eds. Rafael Cano y María Teresa Echenique, II, 311-345. Madrid: Gredos.

Lobato, María Luisa. 2005. «Morfología del entremés de burlas cervantino». En Cervantes y su mundo, III (Estudios de literatura, 92), eds. A. Robert Lauer y Kurt Reichenberger, 283-306. Kassel: Reichenberger.

Luna, Juan de. 1874 [1619]. Diálogos familiares en lengua española, ed. José María Sbarbi. Madrid: Impr. Gómez Fuentenebro.

Luque, Juan de Dios, Antonio Pamies y Francisco José Manjón. 2017. Diccionario del insulto. Barcelona: Ediciones Península.

Ly, Nadine. 1981. La poétique de l'interlocution dans le théâtre de Lope de Vega. Burdeos: Institut d'études ibériques et ibéro-américaines de l'Université de Bordeaux.

Madroñal, Abraham. 2001. «La burla lingüística en el entremés del barroco». En Tiempo de burlas. En torno a la literatura burlesca del Siglo de Oro, eds. Javier Huerta Calvo, Emilio Peral y Jesús Ponce, 177-198. Madrid: Verbum.

Martínez Gavilán, María Dolores. 1988. «Formas de tratamiento en el siglo XVII». Estudios Humanísticos. Filología 10: 85-105.

Medina Morales, Francisca. 2004. «Las formas nominales de tratamiento en el Siglo de Oro. Aproximación sociolingüística». En Memoria de la palabra. Actas del VI Congreso de la Asociación Internacional Siglo de Oro, eds. María Luisa Lobato y Francisco Domínguez Matito, 1329-1341. Madrid - Frankfurt: Iberoamericana - Vervuert. 
Medina Morales, Francisca. 2005. «Cortesía y descortesía en el español de la Edad de Oro a la luz de un complejo sistema lingüístico de tratamientos». Analecta Malacitana 28 (1): 101-140.

Moreno Fernández, Francisco. 2015. Principios de sociolingüistica y sociología del lenguaje, 6. ${ }^{\mathrm{a}}$ impresión de la 4. ${ }^{\mathrm{a}}$ ed. Barcelona: Ariel.

Oesterreicher, Wulf. 1996. «Lo hablado en lo escrito. Reflexiones metodológicas y aproximación a una tipología». En El español hablado y la cultura oral en España e Hipanoamérica, coords. Thomas Kotschi, Wulf Oesterreicher y Klaus Zimmermann, 317340. Madrid - Frankfurt: Iberoamericana -Vervuert.

Oteiza, Blanca. 2013. "Ofensas en el teatro de Tirso de Molina». En Los poderes de la palabra. El improperio en la cultura hispánica del Siglo de Oro, eds. Carmela PérezSalazar, Cristina Tabernero y Jesús M. Usunáriz, 175-189. Nueva York: Peter Lang.

Pérez-Salazar, Carmela. 2002. «Manifestaciones del habla coloquial en un tipo de escrito: las cartas de amor (siglos XVI-XVIII)». En Actas del V Congreso Internacional de

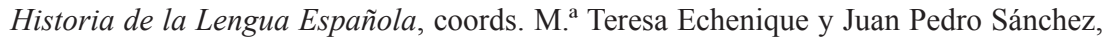
877-890. Madrid: Gredos.

Pérez-Salazar, Carmela. 2018. «Sociolingüística del poder en el Siglo de Oro. De reverencias, altezas, mercedes, señorías y otras formas de tratamiento en el teatro de Calderón de la Barca». Hipogrifo 1 (volumen extraordinario): 97-119.

Pérez-Salazar, Carmela, Cristina Tabernero y Jesús M. Usunáriz, eds. 2013. Los poderes de la palabra. El improperio en la cultura hispánica del Siglo de Oro. Nueva York: Peter Lang.

Pla Cárceles, José. 1923a. «La evolución del tratamiento vuestra-merced». Revista de Filología Española 10: 245-280.

Pla Cárceles, José. 1923b. «"Vuestra merced”>"usted”». Revista de Filología Española 10: 402-403.

Real Academia Española. Aut. Diccionario de autoridades (1726-1739). Accesible en: $<$ https://www.rae.es>.

Real Academia Española. Banco de datos. CORDE [en línea]. Corpus diacrónico del español. Accesible en: <https://www.rae.es> [III-2020].

Real Academia Española. NTLLE. Nuevo tesoro lexicográfico de la lengua española. Accesible en: <https://www.rae.es>.

Rodríguez Mansilla, Fernando. 2006. «Literatura y cortesía en el Siglo de Oro. Del escudero del Lazarillo de Tormes al don Tomé del Bachiller Trapaza». Lexis. Revista de lingüistica y literatura 30(1): 117-141.

Rosal, Francisco del. 1611. Origen y etimología de todos los vocablos originales de la Lengua Castellana. Biblioteca Nacional de España, manuscrito 6929. Accesible en: $<$ https://www.rae.es>.

Sáez Rivera, Daniel Moisés. 2006. «Vuestra merced > usted: nuevos datos y perspectivas». En Actas del VI Congreso Internacional de Historia de la Lengua Española, ed. José Jesús de Bustos Tovar y José Luis Girón Alconchel, III, 2899-2911. Madrid: Arco Libros.

Searle, John R. 1976. «A classification of illocutionary acts». Language in Society 5: 1-23.

Valdés, Juan de. 1990 [1535-1536]. Diálogo de la lengua, ed. Cristina Barbolani. Madrid: Cátedra.

Zimic, Stanislav. 1992. El teatro de Cervantes. Madrid: Castalia. 
